\title{
Fiscal adjustments at the local level: evidence from Colombia
}

\author{
Richard Jaimes ${ }^{1}$ (D) \\ Published online: 24 March 2020 \\ (C) The Author(s) 2020
}

\begin{abstract}
Recent research suggests that intergovernmental grants, own-source revenues, and changes in government investment play a crucial role in helping local governments in advanced economies to adjust their fiscal positions in response to budget shocks. Little is known, however, about the dynamic of local fiscal adjustments in emerging economies, and there are reasons to expect distinct fiscal stabilization patterns, for instance, due to lower fiscal capacity. A panel dataset of more than 900 municipalities in Colombia shows that in line with some of the results for developed countries: (1) intergovernmental grants react significantly to increases in government spending; (2) the response of own-source revenues to innovations in government spending in large cities is higher than in the small ones; (3) government investment is highly volatile and responds to innovations in all other budgetary components; and (4) there is no empirical evidence of a reduction in fiscal effort following increases in intergovernmental grants.
\end{abstract}

Keywords Fiscal adjustment $\cdot$ Local fiscal policy $\cdot$ Fiscal decentralization

JEL Classification $\mathrm{H} 70 \cdot \mathrm{H} 72 \cdot \mathrm{H} 77$

\section{Introduction}

Previous studies on fiscal performance at the local level in advanced economies point out that own-source revenues, intergovernmental grants, and changes in government investment play a major role in helping local governments to adjust their fiscal positions in response to budget shocks (Bessho and Ogawa 2015; Solé-Ollé and Sorribas-Navarro 2012; Buettner 2009; Buettner and Wildasin 2006). In emerging economies, however, there are reasons to expect different fiscal adjustment

Richard Jaimes

R.V.JaimesBonilla@uvt.nl

1 Department of Economics, FIT, and CentER, Tilburg University, Warandelaan 2, 5037 AB Tilburg, The Netherlands 
patterns such as weaker sub-national own-revenue systems, higher levels of fiscal disparities, rent-seeking behavior and corruption, the composition of government spending, coordination failures in the conduct of fiscal policy, and bailout expectations (Bird 2012; Bird and Fiszbein 2008; Acosta and Bird 2005). Despite this widespread view, there is a lack of empirical evidence supporting some of these hypotheses.

This article aims to fill this gap in knowledge by using a panel dataset of more than 900 municipalities in Colombia over the period 1985-2015. The Colombian case is interesting for three reasons. First, it is one of the most decentralized public systems in Latin America. For instance, the share of local spending in total public expenditures increased from 18.5 in 1995 to $36.8 \%$ in 2012, and intergovernmental grants as a percentage of national government expenditures rose from 46.7 in 1995 to $62.9 \%$ in 2012. Second, during the last three decades, Colombia has embarked on a political and fiscal decentralization program. Its purpose has been to transfer responsibilities from higher levels of government to lower ones in order to improve the efficiency in service delivery (Manor 1999; De Mello 2000; Rodden 2002). ${ }^{1}$ Nevertheless, this process is still a work in progress (Bird 2012). Some authors claim that there is a problematic transfer system, limited tax autonomy, and important concerns about how to control sub-national spending to avoid over-borrowing and overspending. Third, over the period of analysis, approximately $10 \%$ of all municipalities in Colombia declared themselves in bankruptcy and followed specific debt restructuring programs under the Law 550 of $1999 .{ }^{2}$ It is thus relevant to recognize the fiscal constraints that Colombian sub-national units face when they react to changes in their budgets and the decisions they make.

Surprisingly, despite the facts that fiscal autonomy to raise own-source revenues and less transfer dependency are associated with higher levels of efficiency in delivering government services (Martínez 2016; Bird 2012), the Colombian fiscal scheme relies on large portions of grants going to local budgets (Faguet and Sánchez 2014; Cortés 2010; Sánchez 2006). For instance, Gemmell et al. (2013) support the hypothesis that if local governments acquire more administrative powers or autonomy to manage their budgets, especially on the side of their revenues, then it will generate higher levels of investment and enhance economic growth. However, as Sánchez (2006) and Martínez (2016) point out, intergovernmental transfers can have a negative effect on the local government behavior in terms of limited incentives to increase their own-source revenues to finance local productive spending. ${ }^{3}$ Although to estimate the effect of grants or own-source revenues in delivery services is an important task, the purpose of this paper, instead, is to assess how

\footnotetext{
1 See Channa and Faguet (2016) and Blume and Voigt (2011) for comprehensive and recent surveys of related work and its shortcomings. In general, the empirical evidence about the impact of more decentralized public systems on economic outcomes has pointed out mixed and inconclusive results.

2 Notice that, however, I exclude these municipalities from the analysis below since I am interested in studying sustainable fiscal policies. A detailed description of the effects of these legal regulations on local public finances in Colombia can be found in MinHacienda $(2015,2016)$.

3 Bonet-Morón et al. (2018) and Cadena (2002) find that the increases in intergovernmental transfers did not have a negative effect on fiscal efforts across municipalities in Colombia.
} 
local governments in Colombia maintain their fiscal solvency in response to budget imbalances, to determine what sort of policies they implement, and the role of intergovernmental grants in this context. Understanding this process is crucial because there is evidence that reductions in government spending or increases in tax rates, following fiscal consolidation programs, could have differential impacts on fiscal sustainability and economic growth (Alesina and Ardagna 2013). ${ }^{4}$

My contribution to the literature in this research is thus threefold. First, I revisit the question about the dynamic interrelationship between revenues and expendituresthat at the local level, by using more disaggregated data on both the revenue and expenditure side following the specification proposed by Bessho and Ogawa (2015). Second, to the best of my knowledge, I provide the first empirical analysis on the fiscal adjustment process at the sub-national level in a developing country and relate the main results to the experiences in advanced economies. Third, given that the local governments in Colombia show important differences in terms of their fiscal autonomy, types of expenditure, and responsibilities (Bird 2012), I also compare the degree of fiscal adjustment across local governments bearing in mind population size, the level of local GDP per capita, and fiscal decentralization indicators.

As in previous studies on fiscal adjustments at the local level, I estimate a panel vector error-correction model assuming that the local governments commit to satisfy an intertemporal budget constraint, in order to evaluate how local governments restore their fiscal solvency over time when they face unexpected changes in their fiscal deficits and public debt levels. In line with the effects reported in some international studies in developed economics, e.g., Japan, Spain, Germany, or the USA (Bessho and Ogawa 2015; Solé-Ollé and Sorribas-Navarro 2012; Buettner 2009; Buettner and Wildasin 2006), my results consistently show that intergovernmental grants and changes in government investment play an important role in helping subnational units to reduce their fiscal deficits. Likewise, my estimations also highlight that there are perverse incentives in the Colombian fiscal scheme since local governments could induce more grants by increasing their spending, a fact that has also been shown for developed countries. Moreover, it is worth noting that, in contrast to the cases in the USA and Germany, own-source revenues in large cities respond to a higher extent to changes in other budgetary variables. This suggests that they could be in a better position to ensure themselves against common and idiosyncratic shocks.

The organization of the paper is as follows. In the next section, I present a brief literature review. In Sect. 3, I describe a basic framework for understanding the intertemporal budget constraint at the local level. In Sect. 4, I present the datasets and point out their main characteristics. In Sect. 5, the empirical strategy is provided.

\footnotetext{
${ }^{4}$ Using data for OECD countries, Alesina and Ardagna (2010) show that in a process of fiscal adjustment, spending cuts, in comparison with tax increases, are related to higher reductions in deficits and debt-to-GDP ratios. For an analysis of the dynamics of debt-to-GDP ratios, see, for instance, Cafiso and Cellini (2014). In the same vein, Glomm et al. (2018) estimate short- and long-run welfare effects of distinct austerity measures and find that spending cuts, relative to tax-based policies, lead to higher steadystate output.
} 
Section 6 describes the specification tests used to estimate the model. In Sect. 7, I point to the main results and perform robustness checks. Section 8 concludes.

\section{Related literature}

This paper contributes to the literature that studies the dynamics of fiscal adjustment at the local level. ${ }^{5}$ For instance, Buettner and Wildasin $(2006,2002)$ analyze these dynamic interrelationships using US municipal data that covers the period 1972 to 1997 . They estimate a vector error-correction model distinguishing own-source revenue, grants, expenditures, and debt service to point out which elements of the budget local governments adjust in response to fiscal imbalances. They find that US municipalities change in a greater extent their government expenditures in response to budget imbalances, but they also present evidence that grants are highly sensitive to local fiscal deficits. In the same line, Buettner (2009) studies the German case during the period 1974-2000 considering the role of fiscal equalization, through intergovernmental grants, on the local fiscal balances. He points out that intergovernmental transfers contribute to restoring the fiscal position in German municipalities in a higher proportion than in US municipalities (two or three times greater). However, he also indicates that despite fiscal equalization transfers, government spending is not less volatile in comparison with the results for US municipalities.

Likewise, Solé-Ollé and Sorribas-Navarro (2012) using the same methodology as Buettner and Wildasin (2006) describe the fiscal adjustment patterns in 258 municipalities in Catalonia, a Spanish region, during the period 1988-2006 and compare their results with those obtained for the USA and Germany in order to take into account institutional arrangement differences. They find out that local governments have incentives to increase their expenditures due to expected bailouts from the central government, and since the majority of sub-national units have a limited fiscal autonomy, the own-source revenue has a lower adjustment capacity in that environment.

In a recent work, Bessho and Ogawa (2015) analyze the Japanese case adopting the same vector error-correction model to estimate local fiscal adjustments. Using a sample of 3210 municipalities for the period 1977-2010 and separating the expenditure side into investment and current spending, they show that the government investment plays an important role in the adjustment process and that possibly there is a presence of flypaper effects. Finally, two other works related to the analysis of the response to budget shocks, which follow the approach proposed by Buettner and Wildasin (2002, 2006), Navon (2006) and Rattso (2004) describe the dynamics of the fiscal adjustment for the cases of Israel and Norway, respectively.

My main departure is that I measure fiscal adjustments to budget shocks at the local level in a developing country and divide the expenditure side into current spending, investment, and debt service as in Bessho and Ogawa (2015) and the revenue side into own-source revenue and intergovernmental transfers, which is an

\footnotetext{
${ }^{5}$ Martín-Rodriguez and Ogawa (2017) provide an excellent recent survey of this literature.
} 
important element in the Colombian local budgets as mentioned above. Likewise, by using the same methodology as previous studies, I am able to provide a comprehensive comparative analysis across economies with different institutional arrangements and development levels.

\section{Analytical framework}

Following Bohn (2007), consider a small open economy so that the standard budget constraint at date $t$ for a particular local government $i=1, \ldots, N$ can be written as follows: 6

$$
B_{i, t+1}+Y_{i, t}=G_{i, t}+\left(1+r_{t}\right) B_{i, t}
$$

where $B_{i, t}$ is the level of debt, $Y_{i t}$ is total revenues, $G_{i, t}$ is the non-interest spending, and $r>0$ is the exogenous interest rate. Thus, I can define the with-interest deficit $D_{i, t}$ as:

$$
D_{i, t} \equiv B_{i, t+1}-B_{i, t}=G_{i, t}+r B_{i, t}-Y_{i, t}
$$

In this setting, $Y_{i . t}$ and $G_{i, t}$ are given by:

$$
\begin{gathered}
Y_{i, t}=R_{i, t}+T_{i, t} \\
G_{i, t}=G C_{i, t}+G I_{i, t}
\end{gathered}
$$

where $R_{i, t}$ is own-source revenues (local taxes), $T_{i, t}$ intergovernmental transfers, $G C_{i, t}$ government consumption and $G I_{i, t}$ government investment. Hence, if I denote the debt services $r B_{i, t}$ as $D S_{i, t}$, then Eq. (2) can be rewritten as:

$$
D_{i, t}=G C_{i, t}+G I_{i, t}+D S_{i, t}-R_{i, t}-T_{i, t}
$$

Likewise, $B_{0}$ is exogenous and the transversality condition $\lim _{t \rightarrow \infty} \frac{B_{t+1}}{(1+r)^{t}}=0$ holds, as it is assumed in the literature, since all debts must be repaid. Notice that in this framework, given a initial level of debt $B_{i, t}$, that in principle $T_{i, t}$ is exogenous because it is determined by central government rules, the local government chooses a spending level $G_{i, t}$, a level of debt for the next period $B_{i, t+1}$ and how much to tax $R_{i, t}$ in order to satisfy its intertemporal budget constraint.

\footnotetext{
${ }^{6}$ It is worth mentioning I follow an accounting approach, similar in spirit to the one developed in Budina and van Wijnbergen (2009), and not a general equilibrium model where governments explicitly maximize welfare.
} 


\section{Data description}

I observe annual budgetary information over the period 1985-2015 for 1033 municipalities in Colombia. In order to assess the intertemporal linkages between local government expenditures and revenues, and to compare results across municipalities taking into account their differences in terms of population, income levels, and fiscal autonomy, I aggregate the budgetary data into five variables as stated above, that is, government consumption, government investment, debt service, intergovernmental grants, and own-source revenues as in Bessho and Ogawa (2015). The fiscal deficit is calculated as described in Eq. (5).

I drop from the dataset observations with inconsistent values such as negative, zero or extremely high values for government investment, government consumption, grants, and/or own-source revenues. After these changes, I ended up with an unbalanced panel of 1014 municipalities. Since I want to analyze sustainable fiscal policies, I also proceed to drop local governments who declared themselves in bankruptcy over the period of analysis (a total of 96 municipalities) and restructured their liabilities by requesting financial protection under the Law 550/1999. Notice that this legal framework allows local governments to recover their fiscal solvency by setting policies based on spending cuts and revenue increases to service the debt under more favorable conditions. ${ }^{7}$ Thus, in the analysis below I use data for 918 municipalities.

Following the previous literature, I decompose the revenue side in two items: first, own-source revenues which include direct taxes, indirect taxes, user charges among others, and second, intergovernmental grants which involve current and capital grants. This item also includes transfers from natural resource exploitation in the form of royalties. Likewise, I divide government spending into three items, that is, government consumption, government investment, and debt service. I compute government consumption as the difference between total spending net of debt services and government investment. The reason to follow that procedure is twofold, on the one hand, to evaluate the role of intergovernmental transfers in the fiscal adjustment path as an additional instrument for fiscal stabilization. On the other hand, by dividing government spending as in Bessho and Ogawa (2015), I am able to assess the trade-off that local governments face when they have to allocate their financial resources between current expenditure and productive spending. ${ }^{8}$

The underlying data come from the National Planning Department and the Center for Economic Development Studies-CEDE (Universidad de Los Andes), with the exception of the price index and population levels, which are obtained from the National Administrative Department of Statistics. All the variables are transformed in per capita basis and deflated to 2008 prices. Thus, values are expressed in millions of 2008 Colombian Pesos (COP). I report the summary statistics for municipalities in Table 1. I present the mean, standard deviation, minimum and maximum values for each variable in both levels and differences. In line with previous studies,

\footnotetext{
7 See Villar et al. (2013) for a detailed explanation of this normative and its fiscal implications.

${ }^{8}$ See Persson (2016) for a discussion about public consumption sensitivity under balanced budget rules.
} 
Table 1 Descriptive statistics (1985-2015, 918 Municipalities)

\begin{tabular}{lcrrr}
\hline Variable & Mean & SD & \multicolumn{1}{l}{ Min. } & Max. \\
\hline G. consumption & 0.097 & 0.074 & 0.000 & 1.683 \\
G. investment & 0.407 & 0.521 & 0.000 & 12.01 \\
Debt services & 0.005 & 0.015 & 0.000 & 0.907 \\
Grants & 0.378 & 0.429 & 0.000 & 9.609 \\
Own-source revenues & 0.118 & 0.184 & 0.000 & 3.667 \\
Deficit & 0.013 & 0.186 & -5.481 & 5.413 \\
$\Delta$ G. consumption & 0.004 & 0.036 & -1.081 & 1.064 \\
$\Delta$ G. investment & 0.043 & 0.284 & -8.027 & 8.954 \\
$\Delta$ Debt services & 0.000 & 0.017 & -0.904 & 0.892 \\
$\Delta$ Grants & 0.028 & 0.216 & -4.982 & 5.411 \\
$\Delta$ Own-source revenues & 0.013 & 0.116 & -2.686 & 1.890 \\
$\Delta$ Deficit & 0.006 & 0.262 & -8.651 & 9.224 \\
Population (thousands) & 36.42 & 240.0 & 0.664 & 7879 \\
\hline
\end{tabular}

Values expressed in per capita basis and in millions of 2008 Colombian Pesos (COP). The underlying data are from the National Planning Department and the National Administrative Department of Statistics

government investment and intergovernmental transfers are the most volatile variables, and debt service seems to be the most stable component in the local government budgets as in advanced economies. However, it is important to mention that while in Colombia average own-source revenues only account for approximately $23 \%$ of total revenues, and in the USA and Germany, own-source revenues attain a participation of around $71 \%$ and $53 \%$, respectively. As mentioned above, these differences relate to the high level of transfer dependency present in Colombia for government spending.

Likewise, Fig. 1 shows the paths of real fiscal variables in Colombian municipalities. It is worth noting that own-source revenues, intergovernmental grants, government consumption, and government investments have been increasing over the whole period as a result of the fiscal decentralization process. Finally, a remarkable feature in the local public finances, which led to the expedition of the Law 550/1999 and subsequent debt and spending regulations such as the Law 617/2000, was the rise in debt services between the years 1993-1999 due to the increase in fiscal deficits across municipalities over those years.

\section{Empirical strategy}

To measure the fiscal adjustments to budget imbalances at the local level in Colombia for the period 1985-2015, I proceed to implement the Buettner and Wildasin (2002, 2006) approach. Since fiscal deficit inclusive of debt services turns out to be stationary, in line with Bohn (1991), government spending (consumption, 


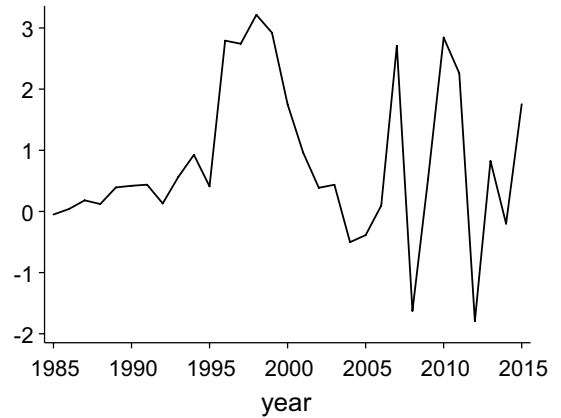

(a) Fiscal Deficit

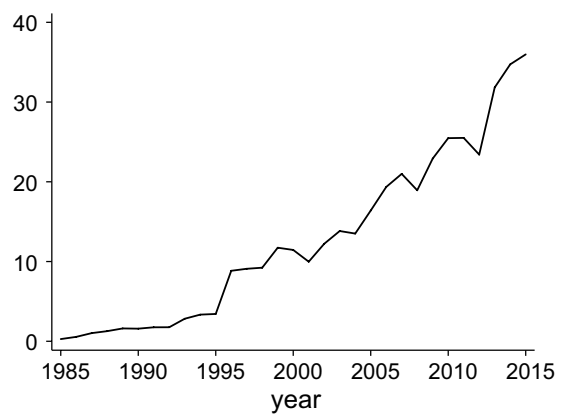

(c) Government Investment

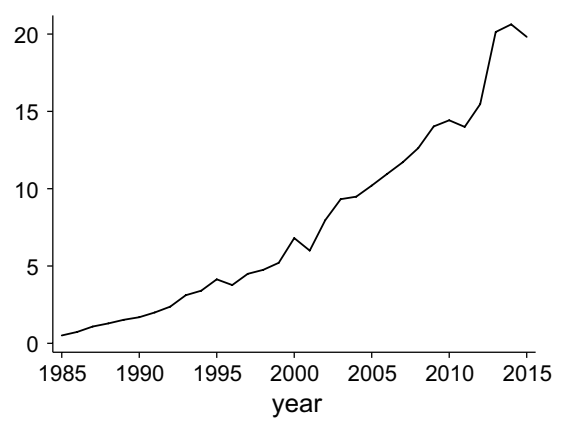

(e) Grants

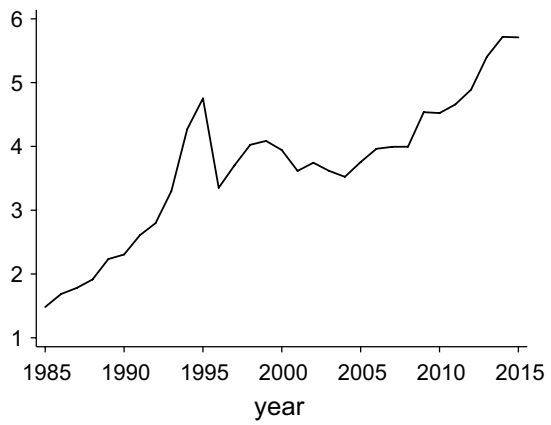

(b) Government Consumption

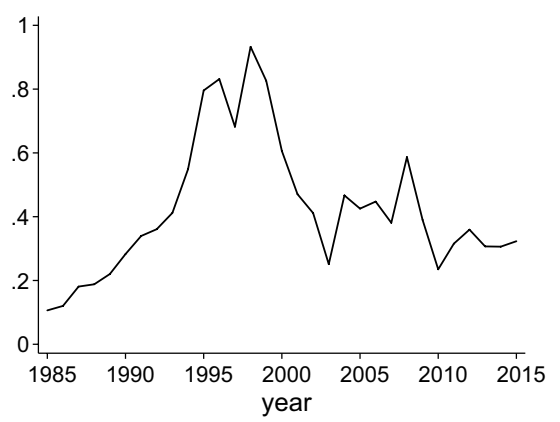

(d) Debt Service

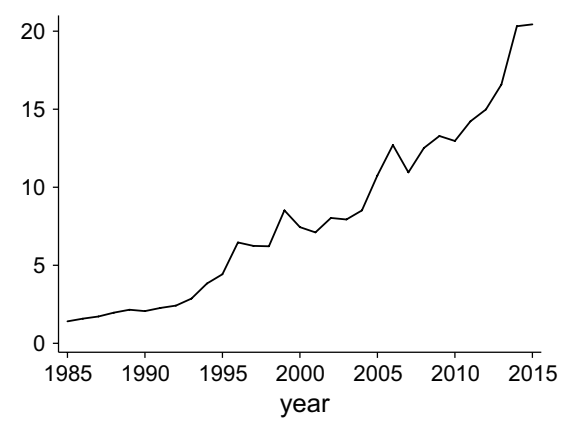

(f) Own-source revenues

Fig. 1 Trends of fiscal variables in Colombian municipalities

investment, debt service) and government revenues (intergovernmental grants and own-source revenues) are cointegrated. ${ }^{9}$

\footnotetext{
9 There is a linear combination of budgetary elements that makes the fiscal deficit stationary, that is, expenditures and revenues move together over time (Lutkepohl 2005).
} 
Thus, I consider a vector error-correction representation of the fiscal deficit, ${ }^{10}$ as defined in the previous section, in the following way:

$$
\Delta X_{i t}=\theta D_{i, t-1}+\sum_{j=1}^{p} \Omega_{j} \Delta X_{i, t-j}+u_{i t}, \quad i=1, \ldots, N, \quad t=1, \ldots, T
$$

where $X_{i t}=\left(G C_{i t}, G I_{i t}, D S_{i t}, R_{i t}, T_{i t}\right)^{\prime}$ and $\psi=(1,1,1,-1,-1)$ forms the known cointegrating vector. Thus, $D_{i t}=\psi^{\prime} X_{i t}$. The idea behind this methodology is to estimate the dynamic interrelationships between the variables that compose the local budget constraint assuming that the with-interest deficit is stationary in the long run. In this sense, $\theta$ and $\Omega_{j}$ are the parameter matrices to be estimated. Following previous studies, I proceed with equation-by-equation OLS estimations without municipality- or time-fixed effects. Nevertheless, I run a set of robustness exercises in order to check the plausibility of this approach.

To interpret the results, I calculate impulse response functions (fiscal reaction functions) in present value terms following Bohn (1991) and Buettner and Wildasin (2002, 2006). By doing that, I can estimate how future local fiscal policy responds to unexpected changes in current fiscal variables. Firstly, I plot impulse response functions for each variable assuming that there are not contemporaneous effects between the variables in the spirit of Buettner and Wildasin (2006) and Buettner (2009). Secondly, following the procedure of Bessho and Ogawa (2015) I summarize the results through the calculation of present value responses to temporal and permanent innovations using a Cholesky decomposition identification scheme based on the variance-covariance matrix.

Note that this identification strategy imposes additional constraints (zero shortrun restrictions on contemporaneous coefficients) since I need to assume the order of the variables to get back to the structural representation for attaining identification of the system (Hamilton 1994). Thus, I begin ordering government spending variables first (government consumption, government investment, debt service) and then revenue variables (intergovernmental grants and own-source revenues). This specific order implies that revenues respond contemporaneously to government spending shocks, but expenditure variables do not respond to innovation in revenue variables within the period. Although this particular approach does not follow a theoretical counterpart, the results are robust to changing the Cholesky ordering, for example, by selecting randomly a specific ordering. In general, the estimated impacts are qualitatively similar and the quantitative differences are small. It is also worth noting that the point estimates do not differ so much from the ones estimated assuming no contemporaneous responses. ${ }^{11}$

\footnotetext{
${ }^{10}$ Notice that I need to check empirically that the assumptions of the model are satisfied. That is, the deficit is a $\mathrm{I}(0)$ process, and that five variables $\left(G C_{i t}, G I_{i t}, D S_{i t}, R_{i t}, T_{i t}\right)$ are $\mathrm{I}(1)$ processes.

11 These estimation results are available upon request.
} 
Table 2 Panel unit-root tests for municipalities

\begin{tabular}{llll}
\hline Lag order (p) & $(1)$ & $(2)$ & $(3)$ \\
\hline Deficit & $-64.0^{* * *}$ & $-37.1^{* * *}$ & $-17.9 * * *$ \\
G. consumption & $-17.8^{* * *}$ & $-3.71 * * *$ & 1.76 \\
G. investment & $-14.9 * * *$ & 1.97 & 11.1 \\
Debt service & $-25.0 * * *$ & $-7.12^{* * *}$ & 0.11 \\
Grants & $-21.5 * * *$ & 0.86 & 5.73 \\
Own revenues & 5.74 & 21.6 & 22.7 \\
$\Delta$ G. consumption & $-112 * * *$ & $-70.3 * * *$ & $-48.0 * * *$ \\
$\Delta$ G. investment & $-106 * * *$ & $-70.6 * * *$ & $-37.6 * * *$ \\
$\Delta$ Debt service & $-110^{* * * *}$ & $-68.3 * * *$ & $-48.9 * * *$ \\
$\Delta$ Grants & $-118^{* * * *}$ & $-71.6 * * *$ & $-47.8 * * *$ \\
$\Delta$ Own revenues & $-75.2 * * *$ & $-35.3 * * *$ & $-12.9 * * *$ \\
\hline
\end{tabular}

Fisher-type unit-root tests using augmented Dickey-Fuller statistics on each panel. Cross-sectional means are removed. All tests include a time trend, except for the deficit. The inverse-normal $Z$ statistic is reported. The sample period is $1985-2015$. The number of municipalities is 917

$* p<0.10, * * p<0.05, * * * p<0.01$

\section{Specification tests}

As stated above, to estimate a vector error-correction model I need to verify that its assumptions are satisfied. Therefore, I proceed to check that the deficit is a I $(0)$ process and that five variables $\left(G C_{i t}, G I_{i t}, D S_{i t}, R_{i t}, T_{i t}\right)$ are I(1) processes. In order to do that, notice that I cannot use the Im et al. (2003) and Pesaran (2007) tests as in previous studies given that I have an unbalanced panel data with gaps in some years. Thus, I employ Fisher-type unit-root tests using augmented Dickey-Fuller statistics on each panel following the procedure proposed by Choi (2001), which also allows me to control for heterogeneity and serially correlated errors. Likewise, to determine the number of $\operatorname{lags}^{12}$ to be included in the OLS estimations and to assess the existence of local-fixed effects ${ }^{13}$, I estimate likelihood-ratio tests for each equation, instead of imposing cross-equation restrictions for the whole system. By doing so, one can get insights about the role of municipality-fixed effects on particular budgetary elements.

\footnotetext{
12 According to the previous literature, the majority of studies have employed a lag length of four years.

${ }^{13}$ I do not include time-specific effects since the intertemporal budget constraint should respond to all innovations and not only to idiosyncratic shocks (Buettner and Wildasin 2006; Buettner 2009). Nevertheless, I estimate the model using time effects and the results are quite similar. Estimations are available upon request.
} 
Table 3 Specification tests for lag order reduction

\begin{tabular}{lll}
\hline Lag length & 4 & 3 \\
\hline$\Delta$ G. consumption & $53.75[0.00]$ & $151.7[0.00]$ \\
$\Delta$ G. investment & $79.52[0.00]$ & $897.1[0.00]$ \\
$\Delta$ Debt services & $411.4[0.00]$ & $609.9[0.00]$ \\
$\Delta$ Grants & $363.3[0.00]$ & $248.7[0.00]$ \\
$\Delta$ Own-source revenues & $124.2[0.00]$ & $401.0[0.00]$ \\
\hline
\end{tabular}

Likelihood-ratio statistics approximately $\chi^{2}$ distributed with 5 degrees of freedom

[ ]: $p$ values

\begin{tabular}{lcc}
\hline Lag length & 4 & 3 \\
\hline$\Delta$ G. consumption & $1012.3[0.01]$ & $885.02[0.76]$ \\
$\Delta$ G. investment & $1139.6[0.00]$ & $1018.6[0.01]$ \\
$\Delta$ Debt services & $240.98[1.00]$ & $188.26[1.00]$ \\
$\Delta$ Grants & $1184.0[0.00]$ & $1067.0[0.00]$ \\
$\Delta$ Own-source revenues & $876.95[1.00]$ & $807.64[1.00]$
\end{tabular}

Likelihood-ratio statistics approximately $\chi^{2}$ distributed with 4580 degrees of freedom

[ ]: $p$ values

\subsection{Panel unit-root tests}

In this subsection, I present the results of panel unit-root tests for each fiscal variable in order to determine their stationarity. Table 2 reports the unit-root statistics for municipalities. The tests for variables in levels include a time trend with the exception of fiscal deficit, and cross-sectional means are removed. I also use different lag orders to control for serially correlated errors. These calculations suggest that the fiscal deficit is stationary and that the first differences of the other budgetary components are also stationary regardless of the lag order which supports the use of the VECM model. I also display the results for the variables in levels. Notice that I cannot reject the null hypothesis that all the panels contain unit roots for own-source revenues with one lag, but once I include three lags I also cannot reject the null for government investment, government consumption, intergovernmental grants, and debt service.

\subsection{Lag selection and local-fixed effects}

In order to determine the optimal lag order, I begin by using four lags for each variable as suggested by the previous literature and then I test for a possible reduction 
in this number. ${ }^{14}$ It is also worth noting that I do not include local-fixed effects ${ }^{15}$ since I introduce variables in first differences and, to a certain extent, one would assume that all local governments should converge to the same deficit level, e.g., zero (Buettner and Wildasin 2006; Buettner 2009; Solé-Ollé and Sorribas-Navarro 2012; Bessho and Ogawa 2015). I check these assumptions using likelihood-ratio tests for the equations of my model.

Tables 3 and 4 report the likelihood-ratio statistics. For instance, the specification of lag order in the first column evaluates whether the dynamics of the model are captured by three lags (the null hypothesis); in this case, the alternative hypothesis suggests using four lags. The reduction of lags is always rejected for all the variables, so in the below estimations, I use a specification with four lags. Likewise, to assess for the necessity of including municipality-fixed effects, I calculate likelihood-ratio tests with two different lag orders in which the null hypothesis assesses whether the model does not require the use of municipality-fixed effects. For instance, using four lags I cannot reject the null hypothesis for government consumption, government investment, and intergovernmental grants. However, when I follow the literature and calculate likelihood-ratio tests on cross-equation restrictions using the variance-covariance matrix of the residuals, I cannot reject the null hypothesis that the model does not require the use of municipality-fixed effects. Therefore, for the next exercises, I proceed with equation-by-equation OLS estimations without fixed effects since joint estimation does not provide gains in efficiency given that I use the same set of variables in each equation (Batalgi 1995; Solé-Ollé and SorribasNavarro 2012).

\section{Main results}

In the next subsections, I show the main results by identifying the type of innovation, e.g., temporal or permanent, and the response for each variable. First, I present municipal responses to positive innovations in budgetary elements over the period of ten years (see Fig. 2). As expected, since the variables are not mean reverting, the impact of innovations does not die out over time, which implies that innovations in this system have permanent effects on the elements composing the government budget constraint. Moreover, these results show that adjustments take place in the first 5-6 years, indicating that local governments require long periods of time to restore their fiscal positions. Second, for the estimations of the present value responses and for the ease of comparison, I assume, in the spirit of the previous

\footnotetext{
${ }^{14}$ See Dahlberg and Johansson (2000) for a discussion about lag-order selection in dynamic panel models.

15 Note that the literature recommends using instrumental variables techniques in dynamic panel data models when lagged dependent variables are included, in order to reduce the OLS estimate bias in short panels Buettner (2009). However, since my sample only contains approximately 30 years for each unit, the Nickell (1981) bias should not be large, and as suggested by Buettner and Wildasin (2006) and Buettner (2009), I could neglect this bias when I proceed to test for local-fixed effects.
} 


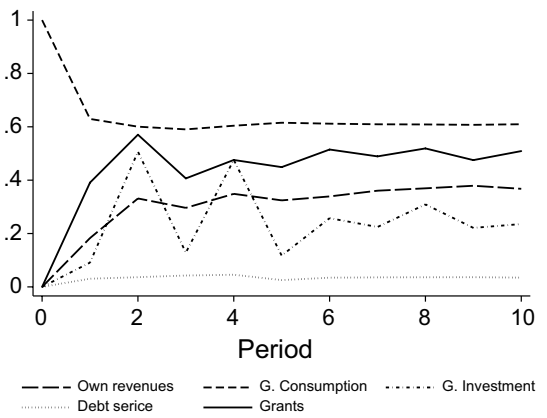

(a) Responses to innovation in $G C$

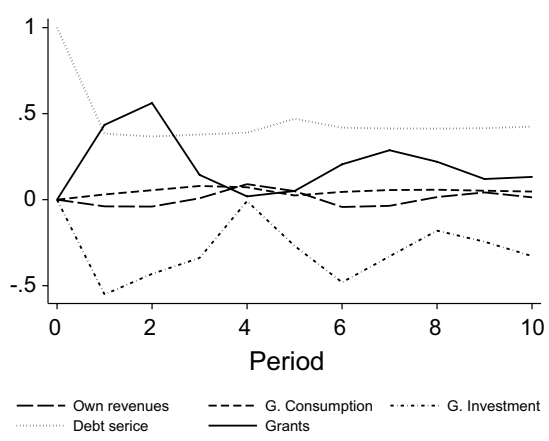

(c) Responses to innovation in $D S$

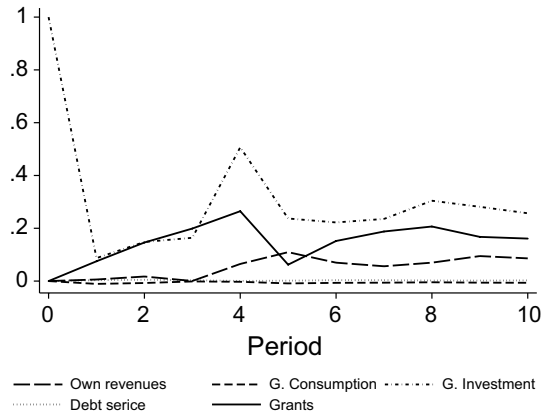

(b) Responses to innovation in $G I$

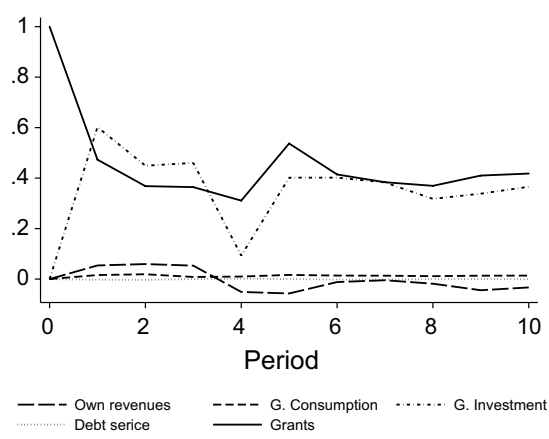

(d) Responses to innovation in $T$

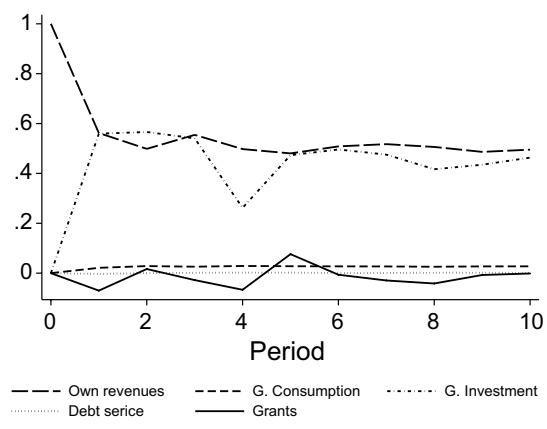

(e) Responses to innovation in $R$

Fig. 2 Impulse response functions

literature, a discount rate of $3 \%^{16}$ and interpret the results according to the procedure of Buettner and Wildasin (2006). ${ }^{17}$

\footnotetext{
16 The results are not sensitive to changes in the discount rate.

17 For more details, see the Appendix.
} 
Table 5 Estimates for the error-correction term in Colombian municipalities

\begin{tabular}{llllll}
\hline Equation & $(1)$ & $(2)$ & $(3)$ & $(4)$ & $(5)$ \\
& G. consumption & G. investment & Debt service & Grants & Own revenues \\
\hline$\theta$ & $-0.02 * * *$ & $-0.49 * * *$ & $0.01 * *$ & $0.24 * * *$ & $0.11^{* * * *}$ \\
Observations & $(0.01)$ & $(0.09)$ & $(0.00)$ & $(0.07)$ & $(0.03)$ \\
Adjusted R-squared & 19,625 & 19,625 & 19,625 & 19,625 & 19,625 \\
\hline
\end{tabular}

Heteroskedasticity robust standard errors in parentheses

$* p<0.10, * * p<0.05, * * * p<0.01$

Table 6 Implied present value responses for Colombian municipalities

\begin{tabular}{|c|c|c|c|c|c|}
\hline & $\begin{array}{l}\text { Innovation to } \\
\text { G. consump- } \\
\text { tion }\end{array}$ & G. investment & Debt service & Grants & Own revenues \\
\hline Response of G. consumption & $\begin{array}{l}-0.38^{* * *} \\
(0.03)\end{array}$ & $\begin{array}{l}-0.01 \\
(0.00)\end{array}$ & $\begin{array}{l}0.05 \\
(0.03)\end{array}$ & $\begin{array}{l}0.01 * * * \\
(0.00)\end{array}$ & $\begin{array}{l}0.03 * * * \\
(0.01)\end{array}$ \\
\hline G. investment & $\begin{array}{l}0.25^{* *} \\
(0.12)\end{array}$ & $\begin{array}{l}-0.72 * * * \\
(0.04)\end{array}$ & $\begin{array}{l}-0.29 * \\
(0.18)\end{array}$ & $\begin{array}{l}0.35 * * * \\
(0.05)\end{array}$ & $\begin{array}{l}0.45 * * * \\
(0.07)\end{array}$ \\
\hline Debt service & $\begin{array}{l}0.03 * * * \\
(0.01)\end{array}$ & $\begin{array}{l}0.00 * * * \\
(0.00)\end{array}$ & $\begin{array}{l}-0.55^{* * *} \\
(0.05)\end{array}$ & $\begin{array}{l}0.00 \\
(0.00)\end{array}$ & $\begin{array}{l}0.00 \\
(0.00)\end{array}$ \\
\hline Grants & $\begin{array}{l}0.48 * * * \\
(0.12)\end{array}$ & $\begin{array}{l}0.16^{* * *} \\
(0.04)\end{array}$ & $\begin{array}{l}0.20 \\
(0.17)\end{array}$ & $\begin{array}{l}-0.58 * * * \\
(0.05)\end{array}$ & $\begin{array}{l}-0.01 \\
(0.06)\end{array}$ \\
\hline Own revenues & $\begin{array}{l}0.38 * * * \\
(0.04)\end{array}$ & $\begin{array}{l}0.08 * * * \\
(0.02)\end{array}$ & $\begin{array}{l}0.03 \\
(0.05)\end{array}$ & $\begin{array}{l}-0.03 \\
(0.02)\end{array}$ & $\begin{array}{l}-0.48^{* * *} \\
(0.04)\end{array}$ \\
\hline $\begin{array}{l}\text { Response to permanent } \\
\text { increase G. consumption }\end{array}$ & & $\begin{array}{l}-0.02 \\
(0.02)\end{array}$ & $\begin{array}{l}0.11 \\
(0.07)\end{array}$ & $\begin{array}{l}0.03^{* * *} \\
(0.01)\end{array}$ & $\begin{array}{l}0.05 * * * \\
(0.01)\end{array}$ \\
\hline G. investment & $\begin{array}{l}0.41^{* *} \\
(0.19)\end{array}$ & & $\begin{array}{l}-0.66^{*} \\
(0.38)\end{array}$ & $\begin{array}{l}0.83 * * * \\
(0.05)\end{array}$ & $\begin{array}{l}0.87 * * * \\
(0.11)\end{array}$ \\
\hline Debt service & $\begin{array}{l}0.06^{* * * *} \\
(0.01)\end{array}$ & $\begin{array}{l}0.01 * * \\
(0.00)\end{array}$ & & $\begin{array}{l}0.00 \\
(0.00)\end{array}$ & $\begin{array}{l}0.00 \\
(0.00)\end{array}$ \\
\hline Grants & $\begin{array}{l}0.77 * * * \\
(0.19)\end{array}$ & $\begin{array}{l}0.58 * * * \\
(0.08)\end{array}$ & $\begin{array}{l}0.44 \\
(0.37)\end{array}$ & & $\begin{array}{l}-0.02 \\
(0.11)\end{array}$ \\
\hline Own revenues & $\begin{array}{l}0.60 * * * \\
(0.07)\end{array}$ & $\begin{array}{l}0.28 * * * \\
(0.06)\end{array}$ & $\begin{array}{l}0.00 \\
(0.11)\end{array}$ & $\begin{array}{l}-0.07 \\
(0.04)\end{array}$ & \\
\hline
\end{tabular}

Standard errors in parentheses

$* p<0.10, * * p<0.05, * * * p<0.01$

\subsection{Results in Colombian municipalities}

Table 5 displays the estimates for the error-correction term in the sample of Colombian municipalities. The vector of coefficients $\theta$ confirms the error-correction 
representation of the fiscal deficit and supports the assumption that the intertemporal budget constraint holds in the long run. Notice that a higher deficit has a negative effect in both types of local government spending, e.g., consumption and investment. Likewise, it has a positive effect on both intergovernmental grants and own-source revenues. Debt service also responds positively which indicates that a higher fiscal deficit results in a rise in debt and, as a consequence, higher levels of debt service should be expected. By comparing these responses with the international evidence for advanced economies in the spirit of Martín-Rodriguez and Ogawa (2017), one can observe that the response of grants to one monetary unit increase in fiscal deficits in Colombia is lower (24 cents) than in Spain (36 cents), but it is surprisingly higher than in the USA ( 7 cents) and Germany ( 5 cents), supporting the idea that the fiscal decentralization process in Colombia is far from being completed as suggested by Bird (2012) although it is worth mentioning that the response of own-source revenues is similar to the ones reported by the USA and Germany.

Table 6 reports the implied present value responses of each fiscal variable to innovations in both itself and other variables. The columns show how fiscal variables adjust after a specific innovation in the system and the rows present how a particular variable reacts to unit changes in other variables. For instance, a 1 COP positive innovation in government consumption in one period is followed by a reduction in future government consumption of 38 cents, and by an increase in government investment of 25 cents, notice that this latter effect could suggest spending complementarity. Intergovernmental grants and own-source revenues react positively to this innovation with an increment of 48 cents and 38 cents, respectively. Given that this rise in government consumption could be financed through debt, there is also a positive effect on debt service of 3 cents. All of these responses are statistically significant.

Furthermore, a 1 COP positive unexpected change in government investment leads to a decrease in future government investment of 72 cents, which implies that the level of investment is 28 cents above the level before the innovation takes place. Notice that in this case, government consumption decreases by 1 cent, but this change is not statistically significant, and the debt service increase is minimal. It is also worth noting that grants and own-source revenues react in a lower extent to a government investment rise (16 cents and 8 cents, respectively) than to a government consumption increase. All of these responses are statistically significant and have the expected sign.

A positive unit innovation in grants is followed by a reduction in future grants of 58 cents and 3 cents in own-source revenues, but this response is not significant. Thus, the latter impact does not support the idea that municipalities who receive more grants tend to decrease their fiscal effort (Martínez (2016); Faguet and Sánchez (2014)), and provides additional empirical evidence for the no existence of fiscal laziness in Colombia (see, e.g., Bonet-Morón et al. (2018) and Cadena (2002)). Notice, however, that these results confirm a possible flypaper effect in Colombian municipalities, given that grants have a positive and significant effect in future spending, particularly in investment, with a total increment of 35 cents. These point estimates are in line with the ones reported for US cities where a rise of one monetary unit in grants generates an increment in expenditures of 34 cents (Buettner 
Table 7 Present value of change in primary surplus in Colombian municipalities

\begin{tabular}{llllll}
\hline & Innovation to G. consumption & G. investment & Debt service & Grants & Own revenues \\
\hline Primary surplus & 0.98 & 0.97 & 0.44 & -0.97 & -0.97 \\
\hline
\end{tabular}

and Wildasin 2006) and for Spanish municipalities where there is a rise in local spending of 29 cents due to an increment in grants (Solé-Ollé and Sorribas-Navarro 2012). For Germany and Japan, the responses attain a value of 35 and 55 cents, respectively, according to the estimates in Buettner (2009) and Bessho and Ogawa (2015). It is also important to mention that, in general, grants can have significant and positive responses to innovations in local public spending which suggests that there is a soft-budget constraint problem given that municipalities may follow an opportunistic behavior (Bessho and Ogawa 2015).

Moreover, a positive innovation in own-source revenues of 1 COP leads to a decrease in grants of 1 cent (but this impact is not significant) and in future ownsource revenues of 48 cents. The impact on debt service has the expected sign, but it is not significant. Government investment reacts positively with a future increment of 45 cents and government consumption with 3 cents. Notice that these impacts are higher in comparison with the responses due to innovations in intergovernmental grants. This fact can be explained bearing in mind that when government revenues come from local taxation and not from an external source, e.g., intergovernmental grants, voters can force local governments to increase productive spending due to a higher level of accountability (Martínez 2016). The impact of innovations on government spending in Colombia is thus quite similar to the reported effects for the USA (51 cents) and Japan (38 cents), but large in magnitude if one compares these values with the ones for Germany (27 cents) and Spain (26 cents).

As suggested by the previous studies, it is also instructive to calculate the responses to permanent innovations (Bessho and Ogawa 2015; Solé-Ollé and Sorribas-Navarro 2012; Buettner 2009; Buettner and Wildasin 2006). The bottom of Table 6 reports those present value responses. Notice that a permanent positive unit innovation in both government consumption and investment is followed by an increment in grants of 77 cents and 58 cents, respectively, supporting again the existence of a soft-budget constraint problem. In addition, future own-source revenues increase by 60 cents and by 28 cents to a unit permanent innovation in government consumption and government investment, respectively. These impacts are similar to the ones computed for US municipalities where the response of own-source revenues to a permanent innovation in total local spending attains 57 cents (Buettner and Wildasin 2006). Moreover, these effects are also similar to the point estimates reported by Bessho and Ogawa (2015) for the Japanese municipalities (51 cents), and by Buettner (2009) for the German municipalities (43 cents). ${ }^{18}$ This could imply that, on average, Colombian municipalities do not face a clear limited fiscal

\footnotetext{
18 Surprisingly, for Spain, Solé-Ollé and Sorribas-Navarro (2012) report a negative and statistically significant response of own-source revenues (-31 cents) to a permanent innovation in general expenditures.
} 
autonomy in terms of capacity to increase their own-source revenues, in contrast to the ideas presented by Bird (2012) and Acosta and Bird (2005).

It is also interesting to assess the response of primary surplus to innovations in each fiscal variable in order to check whether the Colombian municipalities commit to satisfy an intertemporal budget constraint. Indeed, summing up the responses of fiscal variables that constitute the primary surplus, it follows that the absolute value of the changes is close to unity in all cases, but not for debt service (see Table 7). According to Buettner and Wildasin (2006) and Buettner (2009), the latter result in which the fiscal balance is not achieved in response to innovations in debt services could reflect temporal fluctuations in this fiscal variable. Notice that the present value response of debt services to a unit innovation in itself is $-0.55 \mathrm{COP}$, which implies that $0.45 \mathrm{COP}$ of this innovation is permanent. If one compares this value with the present value of the change in primary surplus (0.44) due to a unit innovation in debt services, then one can claim that this result is in line with the predictions derived from an intertemporal budget constraint approach (Bessho and Ogawa 2015; Buettner and Wildasin 2006).

\subsection{Additional results: decomposing the municipal sample}

In this subsection, I proceed to assess whether the above results about fiscal adjustment at the local level in Colombia change when I decompose the municipal sample bearing in mind differences in population levels, local GDP per capita, and degree of fiscal decentralization. ${ }^{19}$ A common perception in the economic literature is that Colombian municipalities have profound disparities, different natural resource abundance, partial fiscal decentralization, high levels of public sector corruption, limited economic opportunities for people, distinct growth rates, and almost no discretion on public spending (Martínez 2016; Bird 2012). In this sense, for instance, it is possible that larger or richer cities follow different patterns of fiscal adjustment since they could have access to more resources and receive more political support from the national government.

Table 8 shows the implied present value responses with respect to city size. I decompose the sample in quartiles using the long-run distribution of population as in Buettner and Wildasin (2006). I only report the results for large cities (top quartile) and small cities (bottom quartile). From the comparison of the point estimates between subsamples, it follows that indeed large cities respond increasing their ownsource revenues in a greater extent than the small cities to a temporal positive unit innovation in both government consumption and government investment with a value of 33 cents and 15 cents, respectively.

Surprisingly, the impact of unexpected changes in both own-source revenues and grants on government spending are quite similar regardless of the size of the city.

\footnotetext{
19 Here, I define the degree of fiscal decentralization using the fiscal decentralization index prepared annually by the National Planning Department. In general terms, this index takes into account fiscal autonomy indicators, in terms of transfer dependency, ability to generate own-source revenues, administrative capacities, among other variables.
} 
Table 8 Implied present value responses with respect to city size

Innovation to G. G. investment Debt services Grants Own revenues
consumption

\section{Large cities (top quartile)}

Response of

$\begin{array}{llllll}\text { G. consumption } & -0.34 * * * & 0.01 & 0.08 & 0.00 & 0.05^{* * *} \\ & (0.06) & (0.01) & (0.07) & (0.02) & (0.01) \\ \text { G. investment } & -0.02 & -0.62 * * * & -0.51^{*} & 0.32^{* * *} & 0.41^{* * *} \\ & (0.16) & (0.10) & (0.31) & (0.08) & (0.11) \\ \text { Debt services } & 0.11^{* * *} & 0.01 & -0.54 * * * & -0.01 & 0.01 \\ & (0.02) & (0.01) & (0.06) & (0.01) & (0.01) \\ \text { Grants } & 0.38^{* *} & 0.22^{* *} & 0.12 & -0.56^{* * *} & -0.08 \\ & (0.16) & (0.09) & (0.28) & (0.07) & (0.10) \\ \text { Own revenues } & 0.33^{* * *} & 0.15^{* * *} & -0.09 & -0.09 * * & -0.42^{* * *} \\ & (0.08) & (0.05) & (0.14) & (0.04) & (0.07)\end{array}$

Response to perma-

nent increase

G. consumption

0.03

0.17

0.01

$0.09 * * *$

(0.09)

(0.16)

(0.04)

(0.02)

G. investment $\quad-0.03$

$-1.13 *$

$0.74 * * *$

$0.71 * * *$

(0.25)

(0.68)

(0.10)

(0.18)

Debt services

$0.17 * * * \quad 0.06$

(0.20)

$-0.01$

0.01

(0.03)

0.47

(0.02)

(0.01)

Grants

$\begin{array}{ll}0.58 * * & 0.47 \\ (0.24) & (0.75)\end{array}$

0.24

$-0.14$

(0.59)

(0.19)

n Own revenues

$\begin{array}{ll}0.49 * * * & 0.47 \\ (0.12) & (0.72)\end{array}$

$-0.19$

$-0.20 *$

(0.31)

(0.10)

Small cities (bottom quartile)

Response of

\begin{tabular}{|c|c|c|c|c|c|}
\hline Expenditures & $\begin{array}{l}-0.40^{* * *} \\
(0.06)\end{array}$ & $\begin{array}{l}-0.01 \\
(0.01)\end{array}$ & $\begin{array}{l}0.03 \\
(0.03)\end{array}$ & $\begin{array}{l}0.01 \\
(0.01)\end{array}$ & $\begin{array}{l}0.02 * * \\
(0.01)\end{array}$ \\
\hline Investment & $\begin{array}{l}-0.03 \\
(0.25)\end{array}$ & $\begin{array}{l}-0.78^{* * *} \\
(0.07)\end{array}$ & $\begin{array}{l}-0.38 \\
(0.25)\end{array}$ & $\begin{array}{l}0.44 * * * \\
(0.11)\end{array}$ & $\begin{array}{l}0.51 * * * \\
(0.12)\end{array}$ \\
\hline Debt service & $\begin{array}{l}0.01 * * \\
(0.00)\end{array}$ & $\begin{array}{l}0.00 \\
(0.00)\end{array}$ & $\begin{array}{l}-0.62^{* * * *} \\
(0.07)\end{array}$ & $\begin{array}{l}0.00 \\
(0.00)\end{array}$ & $\begin{array}{l}0.00 \\
(0.00)\end{array}$ \\
\hline Grants & $\begin{array}{l}0.29 \\
(0.25)\end{array}$ & $\begin{array}{l}0.12 * \\
(0.07)\end{array}$ & $\begin{array}{l}-0.09 \\
(0.23)\end{array}$ & $\begin{array}{l}-0.48^{* * * *} \\
(0.10)\end{array}$ & $\begin{array}{l}0.12 \\
(0.11)\end{array}$ \\
\hline Own revenues & $\begin{array}{l}0.29 * * * \\
(0.08)\end{array}$ & $\begin{array}{l}0.06 * * \\
(0.03)\end{array}$ & $\begin{array}{l}0.09^{*} \\
(0.05)\end{array}$ & $\begin{array}{l}-0.03 \\
(0.04)\end{array}$ & $\begin{array}{l}-0.55^{* * *} \\
(0.06)\end{array}$ \\
\hline Response to perr & nt increase & & & & \\
\hline Expenditures & & $\begin{array}{l}-0.07 \\
(0.06)\end{array}$ & $\begin{array}{l}0.07 \\
(0.08)\end{array}$ & $\begin{array}{l}0.03 * \\
(0.02)\end{array}$ & $\begin{array}{l}0.05 * * \\
(0.02)\end{array}$ \\
\hline Investment & $\begin{array}{l}0.05 \\
(0.41)\end{array}$ & & $\begin{array}{l}-0.97 * \\
(0.56)\end{array}$ & $\begin{array}{l}0.84 * * * \\
(0.10)\end{array}$ & $\begin{array}{l}1.13^{* * *} \\
(0.24)\end{array}$ \\
\hline
\end{tabular}


Table 8 (continued)

Innovation to G. G. investment Debt services Grants Own revenues
consumption

\begin{tabular}{llllll}
\hline Debt service & $0.01^{* *}$ & 0.01 & & 0.00 & -0.01 \\
& $(0.01)$ & $(0.01)$ & & $(0.00)$ & $(0.00)$ \\
Grants & 0.47 & $0.47^{* *}$ & -0.22 & & 0.26 \\
\multirow{2}{*}{ Own revenues } & $(0.41)$ & $(0.22)$ & $(0.56)$ & & $(0.25)$ \\
& $0.49^{* * *}$ & $0.26^{* *}$ & $0.25^{*}$ & -0.07 & \\
& $(0.13)$ & $(0.14)$ & $(0.14)$ & $(0.09)$ & \\
\hline
\end{tabular}

Standard errors in parentheses

$* p<0.10,{ }^{* *} p<0.05, * * * p<0.01$

Notice that, in general, the volatility of government expenditures, debt service, and own-source revenues in small cities is greater than in large municipalities. These results could imply that large cities are in a better position to ensure themselves against common and idiosyncratic shocks. Despite this fact, note that, however, the negative impact on own-source revenues of unexpected changes in grants is only statistically significant for municipalities in the top quartile, giving as a result a reduction of 9 cents in response to a temporal unit innovation in intergovernmental transfers. These estimates could imply that the current fiscal scheme generates perverse incentives in those local governments.

Furthermore, using the local GDP per capita ${ }^{20}$ as an indicator variable of local development, Table 9 displays the present value responses for cities in the top and bottom quartiles for the average local GDP per capita distribution over the period 2000-2009. It is worth noting that for municipalities in the bottom quartile, grants from the national government respond to a greater extent than for municipalities in the top quartile to innovations in government investment. This impact could be explained by the fact that grants in Colombia are distributed following constitutional rules which are based on social indicators, e.g., education attainment, mortality rates, poverty level, so relatively, the majority of grants are allocated to poor municipalities in order to close profound prosperity gaps. At the same time, and in contrast to common wisdom, it seems that poor cities increase their own-source revenues to a higher extent in response to innovation in local public spending.

In addition, I also exploit the variation in the average fiscal decentralization index-FDI-prepared by the National Planning Department over the period 2000-2013 to assess whether municipalities with better administrative capacities, higher fiscal effort, and lower dependence on grants follow a different pattern in terms of fiscal adjustments. Table 10 reports, for instance, that a 1 COP positive innovation in grants is followed by a rise of 42 cents in government investment for municipalities in the top quartile for the average FDI distribution, whereas

\footnotetext{
${ }^{20}$ The estimations of municipal GDP are obtained from the Center for Economic Development StudiesCEDE (Universidad de Los Andes).
} 
Table 9 Implied present value responses with respect to local GDP

Innovation to Investment Debt service Grants Own revenues Expenditures

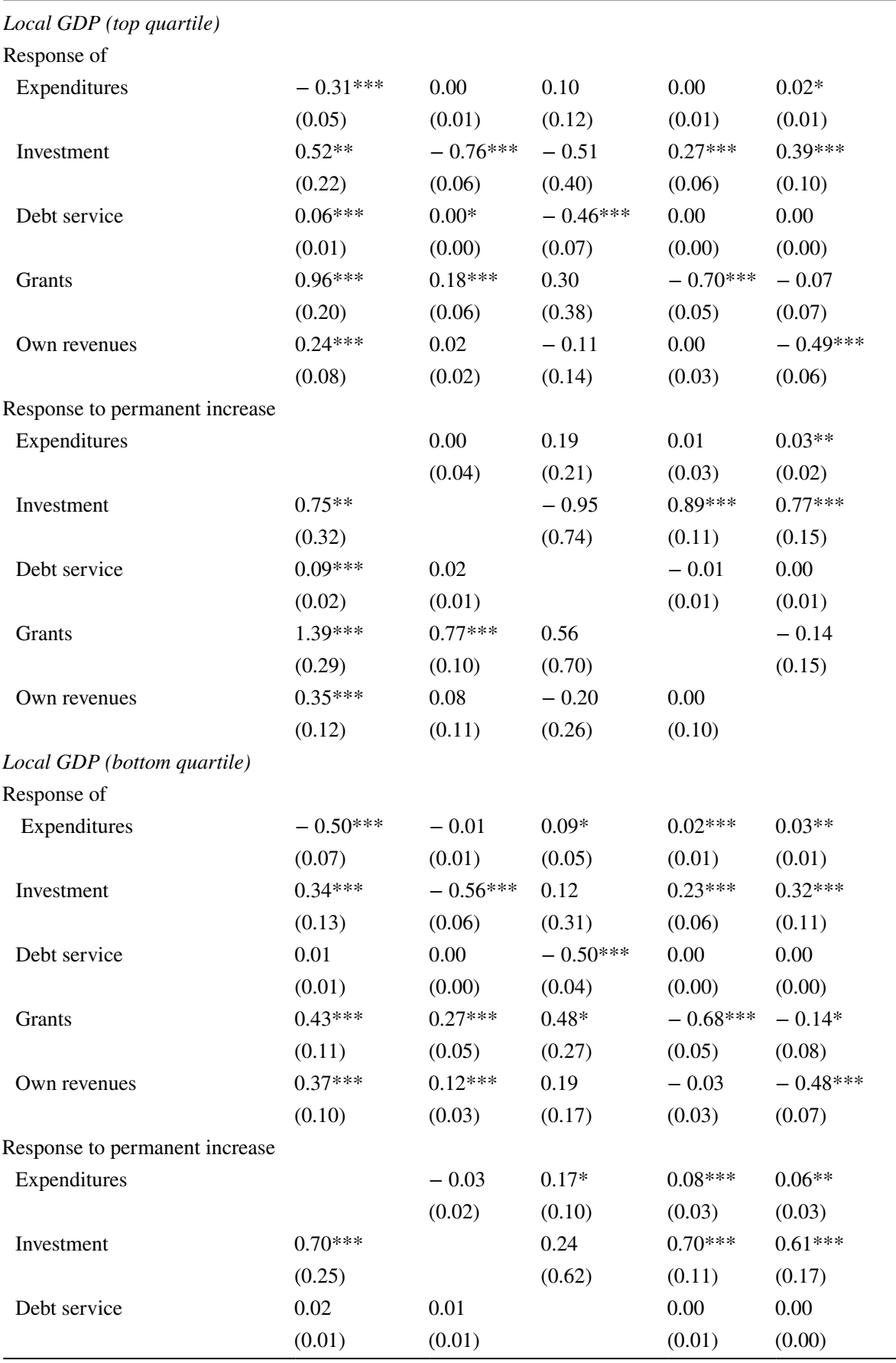


Table 9 (continued)

\begin{tabular}{llllll}
\hline & $\begin{array}{l}\text { Innovation to } \\
\text { Expenditures }\end{array}$ & Investment & Debt service & Grants & Own revenues \\
\hline Grants & $0.87^{* * *}$ & $0.61^{* * *}$ & $0.52^{*}$ & & $-0.27^{*}$ \\
& $(0.18)$ & $(0.07)$ & $(0.52)$ & & $(0.16)$ \\
Own revenues & $0.74 * * *$ & $0.27 * * *$ & 0.38 & $-0.11^{* *}$ & $(0.10)$ \\
& $(0.18)$ & $(0.07)$ & $(0.35)$ & \\
\hline
\end{tabular}

Standard errors in parentheses

$* p<0.10, * * p<0.05, * * * p<0.01$

by 21 cents in the same fiscal variable for municipalities in the bottom quartile. Moreover, as expected, grants for municipalities in the bottom $25 \%$ react in a greater extent to innovations in local spending than for governments in the top quartile. It turns out that intergovernmental grants are going to the more needed municipalities, in order to close their fiscal gaps. Likewise, the response of ownsource revenues to innovations in government consumption is higher for municipalities in the top quartile than for the ones at the bottom, suggesting that, indeed, tax autonomy is an important instrument for fiscal stabilization.

\section{Conclusions}

In this paper, using data over the period 1985-2015, I analyze how local governments in Colombia react to innovations in the fiscal variables that compose their budgets. Using a vector error-correction model, I identify the level of discretion in policy making at the local level in terms of fiscal reaction functions. Contrary to the widespread view of weaker sub-national units in developing economies, in terms of tax autonomy and dependency on intergovernmental grants to finance local public spending, I find that in line with the results for developed countries, government investment is highly volatile and responds significantly to innovations in all other budgetary components and that intergovernmental grants react remarkably to increases in government spending, implying soft-budget constraint problems. Likewise, I show that the response of own-source revenues to innovations in government spending in large cities is higher than their small counterparts, a difference one cannot see in the USA and Germany, supporting the idea of fiscal disparities across Colombian municipalities and the necessity of intergovernmental grants to close these gaps.

Acknowledgements I am indebted to Hernán Seoane for his valuable comments and guidance. I am very grateful to Shun-ichiro Bessho and Hikaru Ogawa for sharing their code to calculate the implied present value responses. I also would like to thank Simon Naitram, Anderson Grajales Olarte, and the participants at the 10th RGS Doctoral Conference in Dortmund, and the GSS Seminar at Tilburg University for useful comments. All errors are my own. 
Table 10 Implied present value responses with respect to a FD Index

Innovation to Investment Debt service Grants Own revenues expenditures

FD Index (top quartile)

Response of

Expenditures

$-0.28 * * *$

$0.00 \quad 0.07$

$0.01 \quad 0.03 * * *$

(0.05)

(0.01) (0.08)

(0.01) (0.01)

Investment

0.08

$-0.77 * * * \quad-0.41$

$0.42 * * * \quad 0.60 * * *$

Debt service

(0.27)

(0.09)

(0.34)

(0.11)

(0.12)

Grants

$0.09 * * *$

$0.01 * *$

$-0.53 * * *$

$0.00 \quad 0.00$

(0.02)

(0.00)

(0.05)

(0.00)

(0.00)

0.34

$0.15^{*}$

0.37

$-0.52 * * * \quad 0.01$

Own revenues

(0.27)

(0.09)

(0.35)

(0.11)

(0.10)

$0.49 * * *$

0.06

$-0.22$

$-0.02$

$-0.36^{* * *}$

(0.13)

(0.04)

(0.17)

$(0.05)$

(0.07)

Response to permanent increase

Expenditures

$\begin{array}{llll}0.01 & 0.14 & 0.01 & 0.05 * * * \\ (0.03) & (0.16) & (0.02) & (0.01) \\ & -0.90 & 0.88 * * * & 0.93 * * * \\ & (0.76) & (0.10) & (0.15) \\ 0.03 & & -0.01 & 0.00 \\ (0.02) & & (0.01) & (0.00) \\ 0.62 * * & 0.79 & & 0.02 \\ (0.24) & (0.74) & & (0.16)\end{array}$

Own revenues

0.26

$-0.47$

$-0.05$

$0.68 * *$

(0.18)

(0.35)

(0.10)

FD Index (bottom quartile)

Response of

Expenditures

$-0.49 * * *$

$-0.01$

0.01

$0.02 * * * \quad 0.02 *$

(0.05)

(0.01)

(0.02)

(0.01)

(0.01)

Investment

$0.29 * *$

$-0.63 * * *$

$-0.08$

$0.21 * * *$

$0.33 * * *$

Debt service

(0.13)

(0.06)

(0.08)

(0.07)

(0.11)

$0.01 * *$

0.00

$-0.61 * * *$

$0.00 \quad 0.00$

(0.00)

(0.00)

(0.08)

(0.07)

(0.11)

Grants

$0.46 * * *$

$0.23 * * *$

$0.20 * *$

$-0.70 * * * \quad-0.10$

(0.11)

(0.04)

(0.10)

(0.05)

(0.07)

Own revenues

$0.29 * * *$

0.10 ***

$0.10 * *$

$-0.04$

-0.51 ***

(0.06)

(0.03)

(0.04)

(0.03)

(0.07)

Response to permanent increase

Expenditures

$\begin{array}{llll}-0.02 & 0.03 & 0.06 * * & 0.04 * \\ (0.02) & (0.04) & (0.02) & (0.02) \\ & -0.21 & 0.69 * * * & 0.68 * * * \\ & (0.22) & (0.14) & (0.18) \\ 0.01 & & 0.00 & -0.01 \\ (0.01) & & (0.01) & (0.01)\end{array}$


Table 10 (continued)

\begin{tabular}{llllll}
\hline & $\begin{array}{l}\text { Innovation to } \\
\text { expenditures }\end{array}$ & Investment & Debt service & Grants & Own revenues \\
\hline Grants & $0.92 * * *$ & $0.62 * * *$ & $0.49 * *$ & & -0.22 \\
& $(0.20)$ & $(0.07)$ & $(0.18)$ & & $(0.15)$ \\
Own revenues & $0.57 * * *$ & $0.27 * * *$ & $0.25 * *$ & -0.14 & \\
& $(0.11)$ & $(0.07)$ & $(0.11)$ & $(0.12)$ & \\
\hline
\end{tabular}

Standard errors in parentheses

$* p<0.10, * * p<0.05, * * * p<0.01$

\section{Compliance with ethical standards}

Conflict of interest The authors declare that they have no conflict of interest.

Open Access This article is licensed under a Creative Commons Attribution 4.0 International License, which permits use, sharing, adaptation, distribution and reproduction in any medium or format, as long as you give appropriate credit to the original author(s) and the source, provide a link to the Creative Commons licence, and indicate if changes were made. The images or other third party material in this article are included in the article's Creative Commons licence, unless indicated otherwise in a credit line to the material. If material is not included in the article's Creative Commons licence and your intended use is not permitted by statutory regulation or exceeds the permitted use, you will need to obtain permission directly from the copyright holder. To view a copy of this licence, visit http://creativecommons.org/licen ses/by/4.0/.

\section{Appendix: Implied present value responses}

I calculate the implied present value responses according to Buettner and Wildasin (2006) and Bessho and Ogawa (2015). The vector error-correction model is given by the following set of equations:

$$
\Delta X_{i t}=\theta D_{i, t-1}+\sum_{j=1}^{p} \Omega_{j} \Delta X_{i, t-j}+u_{i t}
$$

where $X_{i t}=\left(G C_{i t}, G I_{i t}, D S_{i t}, R_{i t}, T_{i t}\right)^{\prime}$ and $\psi=(1,1,1,-1,-1)$ forms the known cointegrating vector. Hence, $D_{i t}=\psi^{\prime} X_{i t}$. Using the fact that I can write the fiscal deficit as $D_{i, t-1}=\psi \Delta X_{i, t-1}+D_{i, t-2}$, following Bohn (1991) and Buettner and Wildasin (2006), I set up a first-order VAR to computed impulse response functions:

$$
Z_{i, t}=\mathbf{F} Z_{i, t-1}+v_{i, t}
$$

such that 


$$
\mathbf{F} \equiv\left[\begin{array}{ccccc}
\Omega_{1}+\theta \psi^{\prime} & \Omega_{2}+\theta \psi^{\prime} & \Omega_{3}+\theta \psi^{\prime} & \Omega_{4}+\theta \psi^{\prime} & \theta \\
\mathbf{I} & \mathbf{0} & \mathbf{0} & \mathbf{0} & 0 \\
\mathbf{0} & \mathbf{I} & \mathbf{0} & \mathbf{0} & 0 \\
\mathbf{0} & \mathbf{0} & \mathbf{I} & \mathbf{0} & \vdots \\
0 & \cdots & 0 & \psi^{\prime} & 1
\end{array}\right], Z_{t} \equiv\left[\begin{array}{c}
\Delta X_{t} \\
\Delta X_{t-1} \\
\Delta X_{t-2} \\
\Delta X_{t-3} \\
D_{t-4}
\end{array}\right], v_{t} \equiv\left[\begin{array}{c}
u_{t} \\
0 \\
\vdots \\
0
\end{array}\right]
$$

where $\mathbf{F}$ is a $(21 \times 21)$ matrix, $\mathbf{I}$ is a $(5 \times 5)$ identity matrix, and $\mathbf{0}$ is a $(5 \times 5)$ zero matrix. Thus, the prediction of the k-period ahead value of $Z_{i, t}$ in response to a unit innovation in period $t$ is given by:

$$
\hat{Z}_{t+k}=\mathbf{F}^{k} v_{i}
$$

where $v_{i}$ identifies the ith budget component in which the innovation takes place. Using a row-selection vector $h_{j}$, which identifies the jth element of interest included in the vector $Z_{t+k}$, it is possible to compute the present value of the response of the jth budget element with respect to a unit innovation in the ith component, in the following way:

$$
\hat{\pi}(j, i)=\sum_{k \geq 1} h_{j} \rho^{k} \mathbf{F}^{k} v_{i}=h_{j} \rho \mathbf{F}[\mathbf{1}-\rho \mathbf{F}]^{-1} v_{i}
$$

where $\rho=1 /(1+r)$ is the discount factor and $r$ is the given interest rate (fixed at $3 \%$ ). The responses to permanent innovations are calculated as follows:

$$
\frac{\hat{\pi}(j, i)}{1-\hat{\pi}(j, i)}
$$

\section{References}

Acosta, O. L., \& Bird, R. (2005). The dilemma of decentralization in Colombia. In R. Bird, J. Poterba, \& J. Slemrod (Eds.), Fiscal reform in Colombia: Problems and prospects (pp. 247-286). Cambridge, MA: MIT Press.

Alesina, A., \& Ardagna, S. (2010). Large changes in fiscal policy: Taxes versus spending. In J. R. Brown (Ed.), Tax policy and the economy (Vol. 24, pp. 35-68). Chicago: University of Chicago Press.

Alesina, A., \& Ardagna, S. (2013). The design of fiscal adjustments. In R. A. Moffitt (Ed.), Tax policy and the economy (Vol. 27, pp. 19-67). Chicago: University of Chicago Press.

Batalgi, B. H. (1995). Econometric analysis of panel data. New York: Wiley.

Bessho, S., \& Ogawa, H. (2015). Fiscal adjustment in Japanese municipalities. Journal of Comparative Economics, 43(4), 1053-1068.

Bird, R. M. (2012). Fiscal decentralization in Colombia: A work (still) in progress. ICEPP Working Papers, 79.

Bird, R. M., \& Fiszbein, A. (2008). Colombia: The central role of the central government in fiscal decentralization. In R. M. Bird \& F. Vaillancourt (Eds.), Fiscal decentralization in developing countries (pp. 172-205). Cambridge: Cambridge University Press.

Blume, L., \& Voigt, S. (2011). Federalism and decentralization: A critical survey of frequently used indicators. Constitutional Political Economy, 22(3), 238-264.

Bohn, H. (1991). Budget balance through revenue or spending adjustments? Some historical evidence for the USA. Journal of Monetary Economics, 27, 333-359. 
Bohn, H. (2007). Are stationarity and cointegration restrictions really necessary for the intertemporal budget constraint? Journal of Monetary Economics, 54, 1837-1847.

Bonet-Morón, J., Pérez-Valbuena, G. J., \& Ricciulli-Marin, D. (2018). ¿Hay pereza fiscal territorial en Colombia? Revista de Economía del Rosario, 21(2), 247-307.

Budina, N., \& van Wijnbergen, S. (2009). Quantitative approaches to fiscal sustainability analysis: A case study of Turkey since the crisis of 2001. The World Bank Economic Review, 23(1), 119-140.

Buettner, T. (2009). The contribution of equalization transfers to fiscal adjustment: Empirical results for German municipalities and a US-German comparison. Journal of Comparative Economics, 37(3), $417-431$.

Buettner, T., \& Wildasin, D. (2002). The dynamics of municipal fiscal adjustment. CESifo Working Paper Series 649, CESifo Group Munich.

Buettner, T., \& Wildasin, D. (2006). The dynamics of municipal fiscal adjustment. Journal of Public Economics, 90, 1115-1132.

Cadena, X. (2002). ¿La descentralización empereza? Efecto de las transferencias sobre los ingresos tributarios municipales en Colombia. Revista Desarrollo y Sociedad, 50, 67-108.

Cafiso, G., \& Cellini, R. (2014). Fiscal consolidations and public debt in europe. International Tax and Public Finance, 21, 614-644.

Channa, A., \& Faguet, J. P. (2016). Decentralization of health and education in developing countries: A quality-adjusted review of the empirical literature. World Bank Research Observer, 31(2), 199-241.

Choi, I. (2001). Unit root tests for panel data. Journal of International Money and Finance, 20(2), 249-272.

Cortés, D. (2010). Do more centralized local governments do better? An evaluation of the 2001 decentralization reform in Colombia. Documentos de Trabajo 007182, Universidad del Rosario.

Dahlberg, M., \& Johansson, E. (2000). An examination of the dynamic behaviour of local governments using GMM bootstrapping methods. Journal of Applied Econometrics, 15, 401-416.

De Mello, L. (2000). Fiscal decentralization and intergovernmental fiscal relations: A cross-country analysis. World Development, 28(2), 365-380.

Faguet, J. P., \& Sánchez, F. (2014). Decentralization and access to social services in Colombia. Public Choice, 160(1), 227-249.

Gemmell, N., Kneller, R., \& Sanz, I. (2013). Fiscal decentralization and economic growth: Spending versus revenue decentralization. Economic Inquiry, 51(4), 1951-1931.

Glomm, G., Jung, J., \& Tran, C. (2018). Fiscal austerity measures: Spending cuts vs. tax increases. Macroeconomic Dynamics, 22, 501-540.

Hamilton, J. (1994). Time series analysis. Princeton: Princeton University Press.

Im, K. S., Pesaran, M. H., \& Shin, Y. (2003). Testing for unit roots in heterogeneous panels. Journal of Econometrics, 115(1), 53-74.

Lutkepohl, H. (2005). New introduction to multiple time series analysis. Berlin: Springer.

Manor, J. (1999). The political economy of democratic decentralization. Directions in development. Washington, DC: The World Bank.

Martínez, L. R. (2016). Sources of revenue and government performance: Evidence from Colombia. Working Paper, LSE.

Martín-Rodriguez, M., \& Ogawa, H. (2017). The empirics of the municipal fiscal adjustment. Journal of Economic Surveys, 31(3), 831-853.

MinHacienda. (2015). Responsabilidad fiscal subnacional y descentralización en colombia: Quince años de consolidación.

MinHacienda. (2016). Efectos de la ley de reestructuración de pasivos (ley 550 de 1999) en las entidades territoriales.

Navon, G. (2006). Budgetary dynamics in the local authorities in israel. Israel Economic Review, 2, 19-52.

Nickell, S. (1981). Biases in dynamic model with fixed effects. Econometrica, 49(6), 1417-1426.

Persson, L. (2016). Government consumption smoothing in a balanced budget regime. International Tax and Public Finance, 23, 289-315.

Pesaran, M. H. (2007). A simple panel unit root test in the presence of cross-section dependence. Journal of Applied Econometrics, 22, 265-312.

Rattso, J. (2004). Fiscal adjustment under centralized federalism: Empirical evaluation of the response to budgetary shocks. FinanzArchiv, 60, 240-261.

Rodden, J. (2002). The dilemma of fiscal federalism: Grants and fiscal performance around the world. American Journal of Political Science, 46(3), 670-687. 
Sánchez, F. (2006). Descentralización y progreso en el acceso a los servicios sociales de educación, salud y agua y alcantarillado. Documentos CEDE 002287, Universidad de los Andes - CEDE.

Solé-Ollé, A., \& Sorribas-Navarro, P. (2012). The dynamic adjustment of local government budgets: Does spain behave differently? Applied Economics, 44, 3203-3213.

Villar, A. d., Liu, L., Mosqueira, E., Schmid, J. P. (2013). Colombia: Subnational insolvency framework. In O. Canuto \& L. Liu (Eds.), Until debt do Us part (pp. 179-219). Washington, DC: The World Bank.

Publisher's Note Springer Nature remains neutral with regard to jurisdictional claims in published maps and institutional affiliations. 